\title{
AKULTURASI ADAT DAN HUKUM ISLAM TERKAIT HARTA WARISAN SUKU MINANGKABAU
}

\author{
Muhammad Ikhsan Ghofur \\ Universitas Islam Negeri Sunan Kalijaga Yogyakarta \\ Email: $\underline{\text { Ikhsan.ghofur@yahoo.com }}$
}

\begin{abstract}
ABSTRAK
Minangkabau adalah suku yang menggunakan sistem matrilineal di mana garis keturunan ibu digunakan. Sistem matrilineal yang diadopsi ini juga mempengaruhi kepemilikan properti yang dimiliki oleh suku ini yang sebagian besar dimiliki oleh perempuan dan dikelola dari ninik (nenek / jangkar) hingga mamak (paman) kemudian dari mamak (paman) hingga kemenakan (keponakan). Selain itu, setiap anggota suku berkewajiban untuk mengembangkan properti itu sehingga mereka tidak memiliki hak atas properti yang dikembangkan. Setelah Islam memasuki wilayah Minangkabau, terjadi transformasi posisi properti rakyat, orang-orang Minangkabau menjadi lebih fokus pada properti keluarga mereka sendiri karena properti suku menjadi properti alternatif. Pemisahan properti dilakukan, yang mana milik orang-orang yang disebut properti warisan dan masih menggunakan sistem adat yang diwariskan, dan properti keluarga yang disebut properti pendapatan di mana hukum Islam digunakan untuk mengatur warisan.
\end{abstract}

Kata Kunci: Minangkabau, Warisan, Properti Warisan, Properti Pendapatan.

\section{ABSTRACT}

Minangkabau is a tribe using matrilineal system where maternal lineages are used. This adopted matrilineal system also affects the property ownership that this tribe has which is owned mostly by women and managed from ninik (grandmother / the anchestor) to mamak (uncle) then from mamak (uncle) to kemenakan (nephew). In addition, each member of the tribe obliged to develop that property so they they don't have the right over their developed property. After Islam entered Minangkabau region, there was transformation of the people property position, the people of Minangkabau became more focus on their own family property since the tribes's property became the alternative property. The property splitting is done, which one belongs to the people that called heritage property and still using inherited custom system, and family property that called income property where Islam law is used to arrange the legacy.

Keyword: Minangkabau, Legacy, Heritage Property, Income Property. 


\section{PENDAHULUAN}

Islam di Indonesia yang sekarang ini lebih dikenal dengan Islam Nusantara memiliki beberapa aspek. Aspek-aspek itu yakni pemikiran, fiqih/hukum, kebudayaan dan politik. Dari beberapa aspek tersebut yang paling menonjol adalah hubungan antara fikih dan kebudayaan, karena apabila berbicara mengenai fikih dan kebudayaan selalu bersinggungan dengan perbuatan-perbuatan syirik yang memang pada awalnya masyarakat nusantara menganut animisme dan dinamisme. Budaya juga menjadi aspek terpenting yang menjadikan Islam diterima di nusantara, karena nusantara kaya akan budaya dan tradisi. Budaya merupakan pikiran, akal, dan budi, sementara kebudayaan adalah hasil kegiatan dan penciptaan batin (akal, budi, dan sebagainya), manusia (seperti kepercayaan, kesenian, adat istiadat, dan sebagainya). ${ }^{1}$ Budaya merupakan olah pikiran manusia belum disampaikan dalam kehidupan, sementara kebudayaan merupakan hasil dari olah pikiran kemudian menjadi kegiatan manusia.

Masuknya Islam ke wilayah nusantara tentunya memberikan dampak kepada kebudayaan yang ada di Nusantara, sehingga memberikan suasana yang baru bagi kebudayaan nusantara ditambah lagi Islam yang masuk tidak merusak kebudayaan yang sudah ada melainkan masuk ke dalam budaya dan menyatu di dalamnya. Salah satu kebudayaan yang telah mengalami perubahan adalah kebudayaan Minangkabau yang mana memiliki kebudayaan tentang harta warisan keluarga yang sekarang tetap

1 Abdul Karim, Islam Nusantara, Yogyakarta: Pustaka Book Publisher, 2007, 122 lestari di masyarakat Minangkabau. Kedudukannya juga tetap terjaga dengan adanya Islam di Minangkabau, sehingga kita masih banyak menemukan lahanlahan hijau di wilayah Minangkabau.

Suku Minangkabau adalah suku di Indonesia yang menggunakan sistem matrilineal di mana garis keturunan berdasarkan garis ibu. Afiliasi utama seseorang adalah terhadap rumah gadang dan kampung suku. Laki-laki menikah dengan dengan anggota keluarga besar tapi tetap terikat pada rumah ibu mereka. Seorang suami dan ayah adalah sosok yang datang dan pergi atau disebut dengan urang sumando. Menurut ungkapan Minangkabau urang semando itu seperti langau di ekor kerbau atau seperti abu di atas tunggul. ${ }^{2}$ Hal seperti itulah yang terjadi di suku Minangkabau, laki-laki hanya bertugas mengelola dari sukunya sendiri tetapi tidak bisa memiliki harta yang dikelola. Orang laki-laki takluk kepada hukum ibu, meskipun dia berusaha, bersawah, berladang, meneruka, kegunaanya bukanlah untuk anaknya, tetapi untuk kemenakannya.

Pepatah Minangkabau mengatakan anak dipangku, kemenakan dibimbing. ${ }^{3}$ Hal ini yang menyebabkan seorang ayah tidak diberi tanggung jawab terhadap anaknya, tetapi dia bertanggung jawab terhadap kemenakannya yang nantinya akan meneruskan harta yang ia kelola. Hal ini tentunya berbeda dengan hukum Islam di mana seorang suami dan ayah bertanggung jawab penuh terhadap istri

2 Jeffrey Hadler, Sengketa Tiada Putus: Matriakat, Reformisme Agama, dan Kolonialisme Agama di Minangkabau, terj. Samsudin Berlian, Jakarta: Freedom Institute, 2010, 9

${ }^{3}$ Hamka Datuk Indomo, Islam dan Adat Minangkabau, Jakarta: Pustaka Panjimas, 1984, 25 
dan anaknya. Harta peninggalan suami juga diwariskan kepada keluarga terdekat terlebih dahulu yaitu istri dan anak. Di dalam adat Minangkabau sendiri harta diwariskan berdasarkan garis keturunan ibu dan pengelolaan dari mamak ke kemenakan, sehingga apabila sebuah keluarga yang mana laki-laki dari keluarga minang sementara perempuan bukan dari keluarga minang maka keluarga tersebut tidak memiliki harta.

Berbedanya sistem yang dijalankan antara adat dan agama Islam tentang harta warisan tentunya ada konflik di dalam suku Minangkabau, namun pada kenyataannya setelah agama Islam memasuki wilayah Minangkabau terjadi penguatan terhadap adat yang tentunya juga berimbas kepada penguatan terhadap harta warisan adat Minangkabau. Antara adat dan agama tidak saling menghilangkan sehingga terdapat harta warisan yang dikelola oleh adat dan ada harta warisan yang dikelola secara ajaran agama Islam. Hal ini dibuktikan dengan adanya pepatah Minangkabau yang mengatakan bahwa "adat bersendi syara', syara' bersendi Kitabullah. Syara' mengata, adat memakai, masjid sebuah, balairung seruang". ${ }^{4}$ Pepatah tersebut menegaskan bahwa adat Minangkabau tidak bertentangan dengan hukum-hukum Islam, sehingga adat sekarang memili nuansa Islam di dalamnya.

\section{Rumusan masalah}

Berdasarkan latar belakang, maka yang menjadi permasalahan dalam penelitian ini adalah bagaimana proses akulturasi budaya Islam dengan adat Minangkabau terkait dengan harta

\footnotetext{
${ }^{4}$ Ibid., 17
}

warisan? Bagaimana kedudukan harta suku Minangkabu setelah mengalami perpaduan antara adat dan agama Islam?

\section{Kajian pustaka}

Penelitian mengenai adat Minangkabau sudah cukup banyak. Penelitian-penelitian yang berkaitan dengan harta pusaka diantaranya adalah:

Pertama, penelitian mengenai kedudukan mamak kepala waris dalam harta pusaka tinggi yang dilakukan oleh Harmita Shah. Penelitian ini dilaksanakan di Nagari Matur Mudiak Kecamatan Matur Kabupaten Agam Propinsi Sumatera Barat. Penelitian ini meneliti tentang kedudukan mamak sebagai kepala waris yang mempunyai wewenang mengurus, mengatur, mengawasi, dan bertanggung jawab atas harta pusaka tinggi. Namun kedudukan itu berubah dikarenakan perubahan sistem perkawinan, keluarnya anggota dari rumah gadang, budaya merantau, perubahan pola pikir dan pekerjaan mamak kepala waris. ${ }^{5}$

Kedua, penelitian mengenai kepemilikan tanah di Minangkabau yang dilakukan oleh Achmad Haykal, Kismiyati El Karimah, dan S Kunto Adi Wibowo dengan judul Konflik Pengetahuan Kepemilikan Tanah di Minangkabau, ${ }^{6}$ penelitian yang lainnya juga dilakukan oleh Fitrianto dengan judul pemilikan tanah menurut adat Minangkabau dalam

5 Harmita Shah, "Kedudukan Mamak Kepala Waris Dalam Harta Pusaka Tinggi (Studi di Nagari Matur Mudiak Kecamatan Matur Kabupaten Agam Propinsi Sumatera Barat)" (Universitas Diponegoro, 2006).

${ }^{6}$ Kismiyati El Karimah Achmad Haykal, dan S Kunto Adi Wibowo, "Konflik Pengetahuan Kepemilikan Tanah di Minangkabau," eJurnal Mahasiswa Universitas Padjadjaran 1, no. 1 (2012). 
perspektif hukum Islam. Penelitian ini dilakukan di Desa Penampuang Puhun.

Pelaksanaan Pembagian Warisan Atas Harta Pencarian Dalam Lingkungan Adat Minangkabau di Kecamatan Lubuk Kilangan Kota Padang karya Ria Agustar. ${ }^{7}$

\section{Landasan teori}

Akulturasi

menurut

Koentjaraningrat merupakan proses sosial yang timbul bila suatu kelompok manusia dengan suatu kebudayaan tertentu dihadapkan dengan unsur-unsur dari suatu kebudayaan asing dengan sedemikian rupa, sehingga unsur-unsur kebudayaan asing itu lambat laun diterima dan diolah ke dalam kebudayaan sendiri tanpa menyebabkan hilangnya kepribadian kebudayaan itu sendiri. ${ }^{8}$ Penulis menggunakan teori ini untuk menganalisis proses terjadinya akulturasi adat dan agama Islam di dalam suku Minangkabau terkait harta warisan yang mana antara adat dan agama terjalin komunikasi yang memposisikan keduanya sesuai aturan masing-masing. Disaat proses akulturasi berlangsung, terdapat hal-hal yang perlu diperhatikan seseorang dalam melihat terjadinya akulturasi. Hal tersebut adalah pertama, tentang keadaan masyarakat penerima sebelum proses akulturasi mulai berjalan. Kedua, individu-individu dari kebudayaan asing yang membawa unsurunsur kebudayaan asing atau disebut dengan agen akulturasi. Ketiga, saluransaluran yang dilalui oleh unsur-unsur kebudayaan asing untuk masuk ke dalam kebudayaan penerima. Keempat, bagian-

7 Ria Agustar, "Pelaksanaan Pembagian Warisan Atas Harta Pencarian Dalam Lingkungan Adat Minangkabau" (Universitas Diponegoro, 2008).

8 Koentjaraningrat, Pengantar Ilmu Antropologi, Jakarta: Angkasa Baru, 1980, 262 bagian dari masyarakat penerima yang terkena pengaruh unsur-unsur kebudayaan asing tadi atau kebudayaan setelah mengalami akulturasi. Kelima, reaksi para individu yang terkena unsur-unsur kebudayaan asing. ${ }^{9}$

Aspek-aspek tersebut digunakan untuk menganalisis proses terjadinya akulturasi. Aspek-aspek tersebut merupakan runtutan terjadinya akulturasi, sehingga akulturasi Islam dengan adat istiadat Minangkabau terkait harta warisan bisa tergambarkan dengan jelas perubahan-perubahannya sebelum dan sesudah Islam memasuki wilayah tersebut.

\section{Metode penelitian}

Penelitian ini menggunakan metode penelitian pustaka untuk mendapatkan data-data mengenai harta warisan suku Minangkabau sebelum, proses, dan sesudah Islam berakulturasi dengan adat Miangkabau. Penelitian pustaka merupakan penelitian yang dilakukan di perpustakaan di mana objek penelitian biasaya digali lewat beragam informasi kepustakaan (buku, ensiklopedi, jurnal ilmiah, koran, majalah, dan dokumen). ${ }^{10}$ Melalui penelitian pustaka, penulis mencari data melalui karya tulisan yang membahas tentang harta warisan Minangkabau agar data tersebut membantu penulis untuk menganalisi proses akulturasi dari adat Minangkabau dan Islam. Sumber data primer dari penelitian pustaka ini adalah buku Adat Minangkabau Menghadapi Revolusi dan Islam Dan Adat Minangkabau karya Hamka. Sumber data sekunder dalam penelitian ini adalah pertama buku karya ${ }^{9}$ Ibid., 266
$10 \quad$ Mestika Zed, Metode Penelitian
Kepustakaan, Jakarta: Yayasan Obor Indonesia, 2008, 89. 
Amir Syarifudin yang berjudul Pelaksanaan Hukum Kewarisan Islam Dalam Lingkungan Adat Minangkabau. Kedua, karya Yaswirmanyang berjudul Hukum Keluarga: Karakteristik Dan Prospek Doktrin Islam Dan Adat Dalam Masyarakat Matrilineal. Ketiga, buku karya Jeffrey Hadler yang berjudul Sengketa Tiada Putus: Matriakat, Reformisme Agama, Dan Kolonialisme Agama Di Minangkabau. Keempat, buku karya Murni Djamal yang berjudul Dr. $H$. Abdul Karim Amrullah: Pengaruhnya Dalam Gerakan Pembaruan Islam Di Minangkabau Pada Awal Abad Ke 20.

Metode dokumentasi adalah suatu cara pengumpulan data yang menghasilkan catatan-catatan penting yang berhubungan dengan masalah yang diteliti, sehingga akan diperoleh data yang lengkap, sah, dan bukan perkiraan. ${ }^{11}$ Semua data yang terkumpul akan dianalisis dengan analisis deskriptif, yaitu rancangan organisasional dikembangkan dari kategori-kategori yang ditemukan dan hubungan-hubungan yang disarankan atau yang muncul dari data. ${ }^{12}$ Secara deskripsi analitik data mengenai proses akuturasi adat dan ajaran agama Islam akan dianalisis dan digambarkan sedemikian rupa sehingga terlihat jelas prose dari akulturasi budaya Minangkabau dan ajaran agama Islam mengenai harta warisan. Analisis deskriptif bertujuan untuk memberikan deskripsi mengenai subjek penelitian berdasarkan data dari varabel yang diperoleh dari kelompok

11 Suwandi Basrowi, Memahami Penelitian Kualitatif (Jakarta: PT Rineka Cipta, 2008). 158

12 Lexy J. Moleong, Metode Penelitian Kualitatif (Bandung: PT Remaja Rosdakarya, 2011). 257 subjek yang diteliti dan tidak dimaksudkan untuk menguji hipotesis. ${ }^{13}$

NEGOSIASI ANTARA ADAT DAN AGAMA ISLAM DALAM PENGATURAN HARTA WARISAN SUKU MINANGKABAU

Pada proses akulturasi antara adat dan agama Islam suku Minangkabau terkait harta warisan berjalan dengan baik meskipun berlangsung cukup lama. Proses akulturasi tersebut menghasilkan pemisahan antara harta milik kaum yang tetap diatur oleh adat dan harta milik keluarga kecil yang diatur oleh agama. Aspek-aspek yang diamati dari proses akulturasi tersebut yaitu: harta pusaka sebelum islam, agen akulturasi harta pusaka, saluran-saluran akulturasi, harta pusaka setelah islam masuk ke wilayah Minangkabau, dan reaksi masyarakat Minangkabau terhadap ajaran Islam terkait harta pusaka.

a. Harta pusaka sebelum Islam

Harta warisan suku Minangkabau atau harta pusaka merupakan harta peninggalan keluarga yang pemanfaatnya digunakan ke dalam satu keluarga dan tidak dibagibagi berdasarkan jumlah keluarga, namun tetap utuh menjadi satu bagian. Harta pusaka mula-mula ditemukan oleh nenek moyang yang mendiami negeri secara menaruko, mencancang, dan melateh. Harta tersebut juga disediakan untuk sanak saudaranya yang kemudian menjadi keluarga yang berkembang dan menjadi suku, sehingga harta tesebut menjadi milik

13 Saifudin Anwar, Metode Penelitian (Yogyakarta: Pustaka Pelajar, 2010). 126 
suku. ${ }^{14}$ Harta pusaka pada awalnya merupakan harta milik nenek moyang karena usahanya sendiri, setelah keturunanya berkembang kemudian harta tersebut dipusakan menjadi harta kaum yang merupakan perkembangan dari keluarga nenek moyang. Dipusakakannya harta tersebut karena harta tidak bisa dibagi-bagi dan dijual oleh salah satu anggota keluarga, sehingga keberadaanya tetap ada bersama dengan keberadaan suku.

Kepemilikan harta pusaka yang dimiliki oleh kaum atau suku, berarti kepemilikannya tidak dimiliki secara pribadi oleh anggota suku. Harta pusaka dimanfaatkan keberadaannya oleh semua anggota suku. Cara memanfaatkannya juga dilakukan secara bergantian. Kepemilikannya merupakan kepemilikan bersama sehingga antara satu sama lainnya saling mengawasi dalam penggunaannya terutama bagi kaum ibu. Hal ini disebabkan dengan sistem matrilineal Minangkabau di mana garis keturunan menggunakan garis keturunan ibu dan pengelola dari ninik ke mamak, kemudian kepada kemenakan, sehingga tidak dari bapak ke anak.

Harta pusaka merupakan milik kaum atau suku, maka apabila suatu kaum atau suku mengalami perkembangan tentunya juga berpengaruh kepada harta pusaka. Sistem ini berlaku karena setiap kaum memiliki hak terhadap harta tersebut. Perkembangan ini terjadi karena setiap anggota suku memiliki kewajiban untuk mengembangkan harta pusaka,

14 Amir Syarifudin, Pelaksanaan Hukum Kewarisan Islam dalam Lingkungan Adat Minangkabau, Jakarta: Gunung Agung, 1984, 227 sehingga harta pusaka semakin berkembang dengan berkembangnya anggota suku. Apabila dalam suatu keluarga tidak ada penerusnya, maka harta tersebut dikembalikan kepada keluarga besar. ${ }^{15}$ Hal ini dikarenakan harta tersebut awalnya milik suatu kaum, sehingga apabila sebuah keluarga mengalami kepunahan atau hilang dalam artian tidak memiliki keturunan perempuan maka dikembalikan kepada kaum.

Setiap anggota yang menaruko hasilnya akan mempengaruhi perkembangan harta pusaka. Hal ini dikarenakan harta yang ditaruko (harta pencarian) akan ditambahkan ke harta pusaka. Setiap pihak yang menaruko tidak memiliki hak atas harta tersebut. ${ }^{16}$ Sistem harta pusaka itu mempertegas bahwa semakin banyak orang melakukan usaha, maka harta usahanya akan tetap kembali kepada harta pusaka. Pengusaha tidak memiliki kekuasaan memiliki harta tersebut. Hal inilah yang menyebabkan harta pusaka suku Minangkabau tetap terjaga karena harta tidak dimiliki secara mutlak tapi dimiliki kemanfaatanya yaitu hasil dari pengelolaan harta pusaka. Pengembangan harta di luar harta pusaka juga akan berdampak pada harta pusaka itu sendiri karena sistem matrilineal yang dimiliki oleh suku Minangkabau di mana laki-laki tidak memiliki harta tersebut, laki-laki hanya bertugas sebagai pengelola, sehingga apabila laki-laki memiliki penghasilan harta akan kembali ke sukunya atau akan dikelola oleh kemenakannya dan

\footnotetext{
${ }^{15}$ Ibid., 228

${ }^{16}$ Ibid., 228
} 
pihak istri memperoleh harta dari sukunya sendiri.

Setiap hasil yang dihasilkan dari harta pusaka, dimanfaatkan oleh anggota kaum. Setiap anggota kaum juga memiliki tugas untuk mengembangkan harta pusaka karena kebutuhan kaum juga meningkat seiring dengan perkembangan anggota kaum, sehingga sebelum Islam memasuki wilayah Minangkabau segala yang berkaitan dengan harta akan kembali kepada suku menjadi harta pusaka baik itu harta yang dihasilkan dari pengembangan harta pusaka maupun harta yang dihasilkan dari usaha keluarga sendiri. Tidak ada pemilahan di dalamnya, dan anak tidak berhak atas harta bapaknya tetapi ia mengelola harta dari mamak-nya.

Hal inilah yang kemudian menjadikan berbagai permasalahan di Minangkabau, diantaranya adalah lakilaki suku Minangkabau bisa beristri dua atau tiga, karena dia tidak memiliki kewajiban menghidupi anaknya tetapi kemenakannya, dan anaknya tersebut juga dihidupi oleh mamak-nya bukan oleh bapaknya. ${ }^{17}$ Permasalahan berikutnya adalah apabila seorang laki-laki sudah tua, maka ia tidak dirawat oleh istri dan anaknya tetapi oleh kemenakannya. ${ }^{18}$

b. Agen akulturasi harta pusaka

Agen-agen akulturari adalah ulama-ulama yang ada di suku Minangkabau dan segala permasalahan yang terjadi terkait harta pusaka yang ada di dalam suku. Ulama-ulama tersebut di antaranya adalah Syeh Ahmad Khatib dan muridnya Syeh

${ }^{17}$ Indomo, Islam dan Adat Minangkabau,

${ }^{18}$ Ibid., 39
Abdulkarim Amrullah. Berdasarkan kedudukan harta pusaka, menurut Syeh Ahmad Khatib, harta pusaka adalah harta yang syubhat. ${ }^{19}$ Fatwa yang diberikan oleh Syeh Ahmad Khatib ini dikarenakan sifatnya yang memiliki kemauan dan berwatak keras, ditambah dengan prinsip keagamaan yang kuat sehingga ia menolak mentah-mentah hal yang bertentangan dengan Islam. ${ }^{20}$ Berbeda dengan syekh Abdul Karim Amrullah yang menyatakan bahwa harta pusaka tinggi adalah waqaf juga, atau sebagai harta mussabalah seperti yang pernah dilakukan oleh Umar bin Khattab pada hartanya sendiri di Khaibar, yang boleh diambil isinya tapi tidak boleh ditasarufkan tanahnya. $^{21}$ Syeh Abdul Karim Amrullah menolak pemikiran Syeh Ahmad Khatib yang mengatakan bahwa harta pusaka di Minangkabau adalah Gasab (kepunyaan yang dirampas dengan paksa), karena telah diwariskan para leluhur Minangkabau kepada generasi-generasi berikutnya. Namun, menurut syekh Abdul Karim harta pusaka tidak bisa dianggap gasab karena para leluhur Minangkabau tidak memperoleh melalui kekerasan atau perampasan, tetapi menerima dengan tangan terbuka, dikelola, dan diwariskan dari satu generasi ke generasi berikutnya. ${ }^{22}$ Perbedaan ini

${ }^{19}$ Ibid., 103

20 Yaswirman, Hukum Keluarga: Karakteristik dan Prospek Doktrin Islam dan Adat dalam Masyarakat Matrilineal, Jakarta: Rajawali Pers, 2013, 154

${ }^{21}$ Indomo, Islam dan Adat Minangkabau, 103

Amrullah: Pengaruhnya dalam Gerakan Pembaruan Islam di Minangkabau pada Awal Abad ke 20, terj. Theresia Slamet, Jakarta: INIS, 2002, 46 
terjadi karena perbedaan masa antara dua ulama tersebut. Syeh Ahmad Khatib yang masa tuanya tinggal di Mekkah dan tidak kembali ke Minangkabau dan belum ada pemisahan antara harta pusaka dan harta pencarian, sehingga ia berpendapat bahwa harta pusaka adalah harta yang syubhat. ${ }^{23}$ Hal ini juga disebutkan oleh Yasmirwan bahwa pada masa Syeh Ahmad Khatib masih berupa harta pusaka, belum dipilah menjadi harta pusaka tinggi dan harta pusaka rendah sebagai upaya mendamaikan antara kaum adat dan ulama tentang harta warisan. ${ }^{24}$ Fatwa tersebut berbeda dengan Syeh Abdulkarim Amrullah yang merupakan murid dari Syeh Ahmad Khatib. Pada masa Syeh Abdulkarim Amrullah sudah ada pemisahan antara harta pusaka dan harta pencarian, sehingga ia menggambarkan harta pusaka sebagai harta mussabalah. Hal ini yang kemudian menjadikan harta pusaka tetap terjaga kedudukannya, karena harta pusaka tetap berada pada kedudukannya dan harta pencarian tidak digunakan untuk menambah harta pusaka.

Ulama yang lainnya yang membantah aturan itu dengan keras selain Syekh Ahmad Khatib adalah Haji Agus Salim. Haji Agus Salim juga hijrah dari Minangkabau sama seperti Syeh Ahmad Khatib. ${ }^{25}$ Era berikutnya yang searah dengan Syeh Abdulkarim Amrullah adalah ulama

103

${ }^{23}$ Indomo, Islam dan Adat Minangkabau,

24 Yaswirman, Hukum Keluarga: Karakteristik dan Prospek Doktrin Islam dan Adat dalam Masyarakat Matrilineal, 154

25 Indomo, Islam dan Adat Minangkabau, 28 perti yang telah menyatakan dalam muktamarnya adalah membantah sikap kehakiman Belanda yang selalu membela adat jikat terjadi perselisihan. Perti juga sefaham dengan mewariskan harta pencarian, sementara untuk harta pusaka mereka lebih memilih diam karena kuatnya adat. ${ }^{26}$

Pemanfaatan harta pusaka juga dilakukan oleh ormas Muhammadiyah dengan mendirikan sekolah. Menurut Syeh Abdul Karim Amrullah bahwa orang Caniago mengizinkan Muhammadiyah memakai tanah pusaka mereka untuk kepentingan umum, kegiatan belajar, dan mendidik anak-anak. Tanah boleh dipergunakan tidak memakai batas waktu, namun hak tanah tetap pusaka tinggi Caniago. Muhammadiyah memakai pusaka tinggi tersebut dengan mengganti kerugian 700 gulden dengan istilah hukumnya adalah Ibaahah. ${ }^{27}$ Hal ini menandakan bahwa harta pusaka hanya digunakan untuk kepentingan bersama, tidak untuk kepentingan pribadi anggota kaum. Posisi tersebut dimanfaatkan oleh ormas Muhammadiyah dalam mendirikan lembaga pendidikan yang pada prakteknya untuk kepentingan bersama.

Selain itu pendapat tersebut, permasalahan yang terjadi di dalam suku Minangkabau semakin menambah perlunya ada perubahan dalam pembagian harta warisan. Permasalahan tersebut diantaranya banyaknya perantauan dari Minangkabau yang sadar akan

${ }^{26}$ Ibid, 27

27 Chairul Anwar, Hukum Adat Indonesia: Meninjau Hukum Adat Minangkabau, Jakarta: Rineka Cipta, 1997, 225 
kedudukan harta pusaka yang mengakibatkan bahwa harta yang mereka cari diperantauan akan menjadi harta kaum. Sehingga orang yang merantau tidak memiliki hak terhadap harta yang dihasilkan oleh meraka. Seperti yang diungkapkan oleh Hamka, bahwa ia menyaksikan sendiri di Pekalongan pada tahun 1924, banyaknya orang Minang yang merantau Pekalongan dengan modal yang besar. Namun, delapan dari sepuluh orang hancur dan kembali dengan kemiskinan. ${ }^{28}$ Hal tersebut terjadi karena harta yang dihasilkan hanya untuk menambah harta pusaka milik kaum dan orang Minangkabau yang merantau tersebut tidak berhak memiliki atas harta yang diusahakannya.

Perkembangan selanjutnya adalah adanya masyarakat yang kemudian mengatasnamakan tanah yang dimilikinya atas nama putranya, hal ini dilakukan agar tanah tersebut tidak diakui oleh kaum atau kemenakannya. ${ }^{29} \mathrm{Hal}$ ini terjadi karena masyarakat minang yang sudah sadar akan kewajibannya terhadap keluarga dan mereka berusaha untuk keluar dari peraturan adat yang ada, sehingga dengan hal tersebut terjadilah perkembangan macam-macam harta yang dimiliki oleh keluarga Minangkabau yang mana terjadi pemisahanan antara harta milik

28 Hamka, Adat Minangkabau Menghadapi Revolusi, Jakarta: Firma Tekad, 1963, 41

29 Hans-Dieter Ever, "CHANGING PATTERNS OF MINANGKABAU URBAN LANDOWNERSHIP," KITLV, Royal Netherlands Institute of Southeast Asian and Caribbean Studies 131, no. XVII (1975), . 96 keluarga besar atau suku dengan harta milik keluarga kecil.

Hal-hal tesebut banyak dilakukan karena ada beberapa kasus yang menyebabkan orang terusir dari tanah pusaka kaum. Kasus tersebut dialami oleh Sutan Kurnia 'Alam, dia merupakan saudagar kaya. Karena hubungan dengan istri terjaga dengan baik dan sudah memiliki anak lakilaki, maka ia membuat rumah di atas tanah pusaka kepunyaan istri. Setelah istri meninggal, ia terpaksa merantau bersama anak-anaknya dikarenakan menurut adat ia tidak boleh tinggal di rumah itu lagi, rumah tersebut kembali kepada suku. ${ }^{30}$ Hal ini tentunya menjadikan masyarakat Minangkabau sadar bahwa usaha-usaha yang mereka lakukan hanya akan menambah harta pusaka milik suku. Kemudian Islam masuk ke wilayah Minangkabau memberikan wawasan baru tentang hukum waris yang berbeda yaitu dari orang tua ke anak menjadikan masyarakat Minangkabau banyak menggunakan hukum Islam, namun hanya sebatas harta yang diusahakannya, tidak menggangu kekdudukan harta pusaka suku.

c. Saluran-saluran akulturasi

Saluran-saluran akulturasi adalah media yang digunakan untuk mengkomunikasikan antara peraturan adat Minangkabau dengan hukum Islam yang berlaku. Saluran-saluran yang digunakan oleh agen-agen akulturasi adalah jalur pendidikan dan musyawarah. Jalur pendidikan di antaranya adalah dengan adanya kaum intelektual, dan seminar, sedangkan

\footnotetext{
30 Hamka, Adat Minangkabau Menghadapi Revolusi, 53
} 
musyawarah adanya pertemuan antara datuk untuk memutuskan masalah adat. Perpaduan antara adat dan agama selain memisahkan antara harta pusaka dan pencarian, juga menguatkan kedudukan harta pusaka tersebut.

$$
\text { Pada tahun 1929, Kongres }
$$

Persatuan Tarbiyah Islamiyah (Perti) yang menyuarakan hati sanubari dari alim ulama pemimpin rohani umat, didukung beberapa pemimpin dari kalangan ninik mamak, menuntut supaya harta pencarian diwariskan menurut hukum faraidh untuk menghindarkan orang Islam dari memakan harta yang haram menurut agamanya. $^{31}$ Kongres tersebut ditindaklanjuti dengan adanya konferensi kepala adat dan ulama Muslim berkumpul di Bukit Tinggi pada tahun 1952, tahun 1968 seminar tentang hukum adat yang makalahnya telah diterbitkan oleh Pusat Studi Minangkabau dan tahun 1971 simposium dengan tema "Tanah Ulayat dan Pembangunan" dari Universitas Andalas. ${ }^{32}$ Simposium tersebut menegaskan tentang kedudukan harta pusaka. Bahwa harta pusaka memiliki peranan terhadap keberlangsungan kehidupan suku Minangkabau. Pemeliharaan properti komunal adalah sebuah dasar dari adat Minangkabau yang berfungsi sebagai sistem hidup. Hal ini secara luas diakui bahwa warisan matrilineal dan kelompok koherensi tergantung pada properti umum dan kepemilikan individu tanah

\footnotetext{
Syarifudin, Pelaksanaan Hukum Kewarisan Islam dalam Lingkungan Adat Minangkabau, 288

32 Hans-Dieter Ever, "CHANGING PATTERNS OF MINANGKABAU URBAN LANDOWNERSHIP," 89
}

akan menyebabkan kematian struktur sosial Minangkabau. ${ }^{33}$ Kongres dan seminar dilakukan agar masyarakat Minangkabau mengetahui perbedaan antara harta pusaka miliki suku yang wariskan kepada suku dan harta pencarian yang diwariskan kepada keluarga. Pemisahan itu dilakukan agar harta pusaka tetap terjaga keutuhannya dan masyarakat dapat berkembang melalui harta pencarian sehingga tidak selalu tergantung kepada harta pusaka milik suku.

Proses musyawarah juga dilakukan untuk memberikan keputusan yang dapat mengkomunikasikan antara hukum adat dan hukum Islam. Pada tahun 1953 diadakan rapat besar di Bukit Tinggi yang dihadiri oleh Bapak Haji Agus Salim. Di dalam rapat tersebut diperkuat pendapat yang telah tumbuh tentang pembagian harta pusaka tinggi dan harta pencarian, sebab sampai saat itu adat belum terpisah dengan agama. ${ }^{34}$ Adapun isi keputusan dari rapat tersebut yaitu:

1) Bahwa harta pusaka (pusaka tinggi) yang telah didapati turun temurun dari nenek moyang menurut garis keibuan diturunkan menurut sepanjang adat.

2) Bahwa pencarian yang menurut adat bernama harta pusaka rendah diturunkan menurut peraturan syara'. 35

Keputusan ini sah menurut adat minangkabau dikarenakan dihadiri oleh penghulu ninik mamak, alim

\begin{tabular}{lll}
\hline & 33 & Ibid., 89 \\
& 34 & \\
& Indomo, Islam dan Adat Minangkabau, \\
Menghadapi Revolusi, 7 & Hamka, Adat Minangkabau
\end{tabular}


ulama, cerdik pandai, dan manti dubalang sebagai utusan dari seluruh alam Minangkabau. Rapat tersebut dihadiri pula oleh Gubernur Sumatera tengah R. Ruslan Mulyoharjo dan wakil dari kementerian Agama R. H. Junaidi. ${ }^{36}$ Melaui hasil rapat tersebut barulah terjadi kesepakan antara hukum adat dan hukum Islam di mana hukum Islam menjadi sumber dari hukum adat dan menguatkan hukum adat itu sendiri. Hamka menyatakan bahwa hasil rapat tersebut juga menghasilkan bahwa harta pusaka tinggi dibiarkan sediakala tidak diganggu-gugat dibiarkan perkembangannya menurut perkembangan zaman. ${ }^{37}$

Kedudukan harta pusaka setelah itu menjadi semakin kuat, dan harta pencarian juga menjadi jelas kegunaan dan fungsinya. Hal tersebut semakin kuat dikarenakan Adat Minangkabau menggunakan sistem tali berpilin tiga yaitu adat, syara', dan undang-undang. Hal tesebut tersunting pada pepatah minang yang berbunyi : Adat bersendi syara', syara' bersendi Kitabullah. Syara' mengata, adat memakai. Syara' bertelanjang, adat bersesamping. Adat menurun, syara' mendaki. $)^{38}$ Antara adat, syara' dan undang-undang saling melengkapi setiap kekurangannya, sehingga adat berlandaskan syara' dan udang-undang yang ada.

d. Harta pusaka setelah Islam

Kedudukan harta pusaka setelah Islam memasuki wilayah Minangkabau, mengalami perubahan.

${ }^{36}$ Ibid., 8

${ }^{37}$ Indomo, Islam dan Adat Minangkabau,

38 Ibid, 106
Pada sebelumnya dijelaskan bahwa semua harta yang ada akan menjadi harta pusaka. Namun, setelah Islam memasuki wilayah Minangkabau terjadi pemilahan terhadap harta pusaka. Harta pusaka dipilah menjadi harta pusaka tinggi dan harta pusaka rendah sebagai upaya mendamaikan kaum adat dengan ulama mengenai harta warisan. ${ }^{39}$

Pemisahan antara harta pusaka dengan pusaka rendah atau pencarian bertujuan agar antara kaum adat dan ahli waris menurut islam tidak mengalami konflik mengenai harta peninggalan orang tua. Harta pencarian juga harus ditegaskan bahwa harta pencarian tersebut hasil usaha sendiri, bukan harta pusaka yang dikembangkan oleh keluarga, sehingga tidak tercampur oleh harta pusaka tinggi. Hal ini dikarenakan setiap anggota suku memiliki kewajiban mengembangkan harta pusaka tinggi dan tentunya sebagai seorang suami memiliki kewajiban menafkahi keluarga, sehingga apabila tercampur maka tentunya akan menimbulkan masalah antara kemenakan dan anak keturunan dari pemimpin keluarga.

Namun, harta pencarian atau pusaka rendah bisa berubah menjadi harta pusaka tinggi apabila semua ahli waris sepakat untuk tetap menjaga keutuhannya tanpa dijual dan dibagi yang kemudian diwariskan secara terus-menerus ke generasi berikutnya hingga sulit untuk menelusuri pembagian harta warisan tersebut. ${ }^{40}$ Hal ini dikarenakan dari pengertian

39 Yaswirman, Hukum Keluarga: Karakteristik dan Prospek Doktrin Islam dan Adat dalam Masyarakat Matrilineal, 154

${ }^{40}$ Ibid., 155 
awal harta pusaka yang mana ditemukan dan dikembangkan oleh nenek moyang dan diwariskan ke generasi selanjutnya. Tentunya pengertian tersebut memperjelas kedudukan harta apablia tidak dibagibagi kepada ahli waris, maka harta tersebut akan menjadi harta pusaka milik keluarga tersebut.

e. Reaksi masyarakat terhadap ajaran Islam

Pencampuran adat dan agama juga menimbulkan permasalahan baru. Menurut adat, harta diwariskan mamak kepada kemenakan dan menurut Islam harta diwariskan kepada anak. Hal tersebut menyebabkan bapak-bapak di Minangkabau semasa hidupnya menghibahkan harta bendanya kepada anak-anaknya agar sang anak memilikinya ketika bapak meninggal. Hal ini dilakukah agar kemenakan tidak menganggap mereka berhak atas harta peninggalan mamaknya. ${ }^{41}$

Konflik tersebut terjadi karena ahli waris menganggap mereka berhak, dan kemenakan juga merasa mereka berhak. Karena belum ada pemisahan antara harta pusaka dan harta pencarian. Sehingga untuk mengantisipasi hal tersebut pihak orang tua melakukan hibah kepada anaknya. Perolehan ahli waris juga perlu diselidiki seberapa besar orang tua tersebut menggunakan harta pusaka untuk digunakan sebagai modal harta pencarian atau orang tua mengadakan harta pencarian atas usaha sendiri. Sehingga setelah dipisahkan antara harta pusaka yang digunakan dalam harta pencarian, barulah harta tersebut

${ }^{41}$ Chairul Anwar, Hukum Adat Indonesia: Meninjau Hukum Adat Minangkabau, Jakarta: Rineka Cipta, 1997, 97 bisa dibagikan sesuai ketentuan yang berlaku. Harta pusaka yang dipakai diberikan sesuai adat, sementara harta pencarian yang diberikan sesuai dengan hukum syara'.

Berbagai cara dilakukan agar hukum Islam dapat diterima di adat Minangkabau di mana antara adat dan hukum Islam bertentangan di dalamnya. Namun, pada kenyataanya hukum Islam dapat diterima dengan baik dan bahkan justru menguatkan kedudukan adat. Hal ini terbukti dengan masyarakat Minangkabau yang masih kental dengan ajaran Islamnya. Kemudian, pada harta warisan yang menjadi ciri khas dan martabat suku Minangkabau justru setelah ada Islam, kedudukannya semakin bertambah jelas yang mana harta pusaka tetap berada pada suku dengan peraturan adat dan Islam menguatkannya dengan pendapat ulama Minangkabau yang menghukumi harta tersebut dengan harta mussabalah dan harta pencarian diserahkan kepada hukum Islam. Hal ini pentimg dilakukan agar pada perkembangan selanjutnya tidak terjadi perebutan antara keluarga Minangkabau yang mana ada saling klaim terhadap harta yang ada. Selain itu, dengan adanya pemisahan tersebut masyarakat Minangkabau dapat mengembangkan usaha miliknya sendiri karena harta tesebut nantinya dapat digunakan oleh ahli warisnya, dan apabila ahli waris tidak membagi dengan hukum Islam yang ada maka harta peninggalan orang tua akan menjadi harta pusaka keluarga tersebut yang pemanfaatanya bisa kepada generasi selanjutnya.

\section{KESIMPULAN}


Berdasarkan penelitian pustaka yang telah dilakukan terhadap proses akulturasi adat dan hukum Islam terkait harta warisan suku Minangkabau dapat disimpulkan bahwa:

Pertama, proses akultuarasinya terjadi melalui jalur pendidikan dan musyawarah yang dilakukan oleh tokohtokoh agama Minangkabu. Selain itu permasalahan yang timbul terkait dengan harta warisan juga memicu terjadinya proses akulturasi tersebut, sehingga terjadilah musyawarah antara pemuka agama dan pemuka adat untuk memisahkan antara harta pusaka milik suku yang mana menggunakan hukum waris adat dan harta pencarian milik keluarga menggunakan hukum waris Islam.

Kedua, Harta pusaka sebelum Islam masih berupa satu kesatuan utuh. Setiap anggota berhak untuk menggunakannya, tetapi juga memilki kewajiban untuk mengembangkannya dengan cara menaruko. Hasil taruko yang berupa harta pencarian akan disatukan kepada harta pusaka, agar harta tersebut selalu bertambah sesuai dengan perkembangan anggota kaum. Setelah proses akulturasi antara adat dan Islam menghasilkan pengukuhan terhadap harta pusaka yang mana kedudukannya semakin kuat karena identitas hukumnya jelas dengan adanya Islam. Kedudukan harta pusaka juga sudah berubah menjadi harta cadangan suatu kaum. Karena setiap anggota sudah memiliki harta pencarian.

\section{DAFTAR PUSTAKA}

$\begin{array}{crr}\text { Abdul } \quad \text { Karim, } & \text { Islam } & \text { Nusantara, } \\ \text { Yogyakarta: } & \text { Pustaka } & \text { Book } \\ \text { Publisher, 2007 } & & \end{array}$

Achmad Haykal, Kismiyati El Karimah, dan S Kunto Adi Wibowo. "Konflik Pengetahuan Kepemilikan Tanah Di Minangkabau." eJurnal Mahasiswa Universitas Padjadjaran 1, no. 1 (2012)

Agustar, Ria. "Pelaksanaan Pembagian Warisan Atas Harta Pencarian Dalam Lingkungan Adat Minangkabau." Universitas Diponegoro, 2008

Amir Syarifudin, Pelaksanaan Hukum Kewarisan Islam dalam Lingkungan Adat Minangkabau, Jakarta: Gunung Agung, 1984

Anwar, Saifudin. Metode Penelitian. Yogyakarta: Pustaka Pelajar, 2010

Basrowi, Suwandi. Memahami Penelitian Kualitatif. Jakarta: PT Rineka Cipta, 2008

Chairul Anwar, Hukum Adat Indonesia: Meninjau Hukum Adat Minangkabau, Jakarta: Rineka Cipta, 1997

Hamka Datuk Indomo, Islam dan Adat Minangkabau, Jakarta: Pustaka Panjimas, 1984

Hans-Dieter Ever, "CHANGING PATTERNS OF MINANGKABAU URBAN LANDOWNERSHIP," KITLV, Royal Netherlands Institute of Southeast Asian and Caribbean Studies 131, no. XVII (1975)

Harmita Shah, "Kedudukan Mamak Kepala Waris Dalam Harta Pusaka Tinggi (Studi di Nagari Matur Mudiak Kecamatan Matur Kabupaten Agam Propinsi Sumatera 
Barat)" (Universitas Diponegoro, 2006)

Jeffrey Hadler, Sengketa Tiada Putus: Matriakat, Reformisme Agama, dan Kolonialisme Agama di Minangkabau, terj. Samsudin Berlian, Jakarta: Freedom Institute, 2010

Kismiyati El Karimah Achmad Haykal, dan S Kunto Adi Wibowo, "Konflik Pengetahuan Kepemilikan Tanah di Minangkabau," eJurnal Mahasiswa Universitas Padjadjaran 1, no. 1 (2012)

Koentjaraningrat, Pengantar Ilmu Antropologi, Jakarta: Angkasa Baru, 1980

Mestika Zed, Metode Penelitian Kepustakaan, Jakarta: Yayasan Obor Indonesia, 2008

Moleong, Lexy J. Metode Penelitian Kualitatif. Bandung: PT Remaja Rosdakarya, 2011

Murni Djamal, Dr. H. Abdul Karim Amrullah: Pengaruhnya dalam Gerakan Pembaruan Islam di Minangkabau pada Awal Abad ke 20, terj. Theresia Slamet, Jakarta: INIS, 2002

Ria Agustar, "Pelaksanaan Pembagian Warisan Atas Harta Pencarian Dalam Lingkungan Adat Minangkabau" (Universitas Diponegoro, 2008)

Shah, Harmita. "Kedudukan Mamak Kepala Waris Dalam Harta Pusaka Tinggi (Studi Di Nagari Matur Mudiak Kecamatan Matur Kabupaten Agam Propinsi Sumatera
Barat)." Universitas Diponegoro, 2006

Yaswirman, Hukum Keluarga: Karakteristik dan Prospek Doktrin Islam dan Adat dalam Masyarakat Matrilineal, Jakarta: Rajawali Pers, 2013 